\title{
Dynamics and Distribution of Trunk- injected Phosphite in Coconut Palm
}

\author{
Jiaming Yu, Timothy K. Broschat ${ }^{1}$, William G. Latham, \\ and Monica L. Elliott \\ University of Florida, Fort Lauderdale Research and Education Center, \\ 3205 College Avenue, Davie, FL 33314
}

Additional index words. phosphonate, fungicide, Cocos nucifera

\begin{abstract}
Palms are an important component of landscapes in tropical, subtropical, and Mediterranean climates, but are anatomically very different from broadleaf trees. Very little is known about the movement and persistence of systemic fungicides into various parts of the palm canopy. This information is critical in selecting fungicides that may be effective against diseases that infect specific parts of the palm. In this study, potassium phosphite was injected into mature coconut palms (Cocos nucifera) at rates of $0,30,60$, or $90 \mathrm{~mL}$ per tree. Various leaf tissue samples were collected periodically thereafter up through 60 weeks and were analyzed for phosphite concentrations. Phosphite moved quickly into leaflet tissue, but concentrations dropped off sharply between 1 and 5 weeks after injection. This drop in leaflet concentrations was balanced by a concomitant increase in spear leaf concentrations. Phosphite persisted at high concentrations in basal rachis tissue of both old and new leaves throughout the experiment. This suggests that this material may be useful for controlling diseases that infect spear leaves and petiole or rachis tissue, but not leaflets.
\end{abstract}

Phosphites (syn. phosphonates) $\left(\mathrm{H}_{2} \mathrm{PO}_{3}^{-}\right.$; $\mathrm{HPO}_{3}{ }^{2-}$ ) are alkali metal salts of phosphorous acid $\left(\mathrm{H}_{3} \mathrm{PO}_{3}\right)$, a reduced form of phosphate $\left(\mathrm{PO}_{4}{ }^{3-}\right)$. Because phosphite has one less oxygen molecule, it has a higher degree of solubility and mobility than phosphate. This characteristic gives phosphite the ability to rapidly cross the membranes of leaves or roots. It is considered an ambimobile ion, which means it has both xylem and phloem mobility (Guest and Grant, 1991; Ouimette and Coffee, 1990).

Although it is often sold as a fertilizer, phosphite cannot be metabolized as a phosphorus source by plants (McDonald et al., 2001; Ratjen and Gerendás, 2009; Thao and Yamakawa, 2009). However, phosphite has been effective in controlling plant diseases, especially those caused by Phytophthora spp. (Guest and Grant, 1991; Smillie et al., 1989), including Phytophthora diseases of palms (DeFranqueville and Renard, 1989; Pohe et al., 2003; Thévenin et al., 1995). Phosphite compounds have also been effective in controlling diseases caused by Fusarium spp., Rhizoctonia solani, and Microdochium majus in other crops (Hofgaard et al., 2010; Lobato et al., 2008, 2010).

The mode of action of phosphite is complex and is not fully understood. Phosphite

\footnotetext{
Received for publication 17 Apr. 2015. Accepted for publication 13 July 2015.

This research was supported by the Florida Agricultural Experiment Station and by the USDA National Institute of Food and Agriculture Hatch Project FLA-FTL-004945.

We thank Susan Thor and Elizabeth Desjardin for their assistance in this project.

${ }^{1}$ Corresponding author. E-mail: tkbr@ufl.edu.
}

has been shown to have direct effects on Phytophthora spp. and other fungi, both in vitro and in vivo. However, it is believed that the primary mode of action of phosphite is through its stimulation of natural plant defense mechanisms (Guest and Grant, 1991; Smillie et al., 1989). The benefits of phosphite as a fungicide include low cost, high mobility within plants, persistence in plant tissue, multiple action sites as a fungicide, and low mammalian and environmental toxicity (Guest and Grant, 1991). Phosphite compounds are typically applied to herbaceous plants using foliar sprays or soil drenches. However, to improve effectiveness and reduce the amount of chemical applied as well as potential environmental impacts, trunk injection is increasingly being used for application on tree crops (Guest et al., 1994, 1995; VanWoerkom et al., 2014). Since trunk injections cause permanent wounds in palms, this method is recommended only for prevention of lethal diseases.

Knowledge of phosphite distribution and dynamics in plant tissues is essential to determine the optimum timing for fungicide treatment and to predict which diseases it may be effective against. A study on the distribution and dynamics of phosphite in avocado (Persea americana) trees treated with fosetyl-Al (the active breakdown product of this fungicide is phosphite) showed that phosphite concentrations were higher in branches than in the roots or leaves (Bezuidenhout et al., 1987). Its concentration in the branches and root samples taken from avocado trees reached its peak a month after trunk injection of fosetyl-A1. However, in mature leaves, the phosphite peak was broader. As a result, old branches stored $\approx 50 \%$ of the phosphite, the roots around $30 \%$, and the remaining $20 \%$ was in young branches, leaves, and leaf stems. The conclusion from this study was that phosphite was not evenly distributed among different plant organs.

Although phosphite fungicides have been evaluated for disease control in palms (Darakis et al., 1985; DeFranqueville and Renard, 1989; Thévenin et al., 1995), nothing is known about the distribution and dynamics of phosphite in palms. Because palms are arborescent monocots, they differ greatly from dicot trees in their anatomy and physiology, making it difficult to extrapolate the results of research done on dicot trees to palms. The objectives for this study are to determine the uptake, distribution, and persistence of phosphite in trunk-injected coconut palms over time.

\section{Materials and Methods}

Twenty malayan dwarf coconut palms growing at the University of Florida's Fort Lauderdale Research and Education Center, Davie, FL were used in this study. These palms were $\approx 30$ years old, $8-10 \mathrm{~m}$ in overall height, and were fruiting at the time of this study. The palms were growing in a Margate fine sand soil, with individual palms spaced $\approx 6 \mathrm{~m}$ apart. Palms were fertilized every 3 months by broadcasting an $8 \mathrm{~N}-0.9 \mathrm{P}-10 \mathrm{~K}-$ $4 \mathrm{Mg}$ plus micronutrients controlled-release fertilizer (Nurserymen's Sure-Gro Corp., Vero Beach, FL) at a rate of $75 \mathrm{~g} \cdot \mathrm{m}^{-2}$ to the entire plot.

The Arborjet tree I.V. Microinfusion system (Arborjet Inc., Woburn, MA) was used to inject the following four treatments: deionized water (DI) only (control), $30 \mathrm{~mL}$ (8.4 g a.i.) potassium phosphite, $60 \mathrm{~mL}$ (16.8 g a.i.) potassium phosphite, and 90 $\mathrm{mL}(25.2 \mathrm{~g}$ a.i.) potassium phosphite. All phosphite treatments were diluted 1:2 with DI. The commercial source of the potassium phosphite was StarPhite (Loveland Products Inc., Greeley, CO). Holes $9.5 \mathrm{~mm}$ in diameter and $10-\mathrm{cm}$ deep were drilled $\approx 1 \mathrm{~m}$ above the ground. All of the holes were on the south side of the trunk. Treatments were replicated five times and were arranged in a completely randomized design. Injections were performed on 17 May 2012.

Plant tissues were harvested at $1,5,10$, $15,20,30,40,50$, and 60 weeks after application. The following plant tissues were harvested to determine phosphite distribution within coconut palm: spear leaf (youngest unopened leaf) tip, rachis base of the oldest leaf (OBR), middle leaflets from the oldest leaf (OML), and middle leaflets from the youngest fully expanded leaf (YML) (Fig. 1). Coconut palms produce about one new leaf every 5 weeks. Thus, a different spear leaf tip was harvested each time, as were leaflets from youngest fully expanded leaf and old leaf. To sample the rachis from the oldest leaf, this leaf was cut from the canopy. Since untreated (DI only) palm 


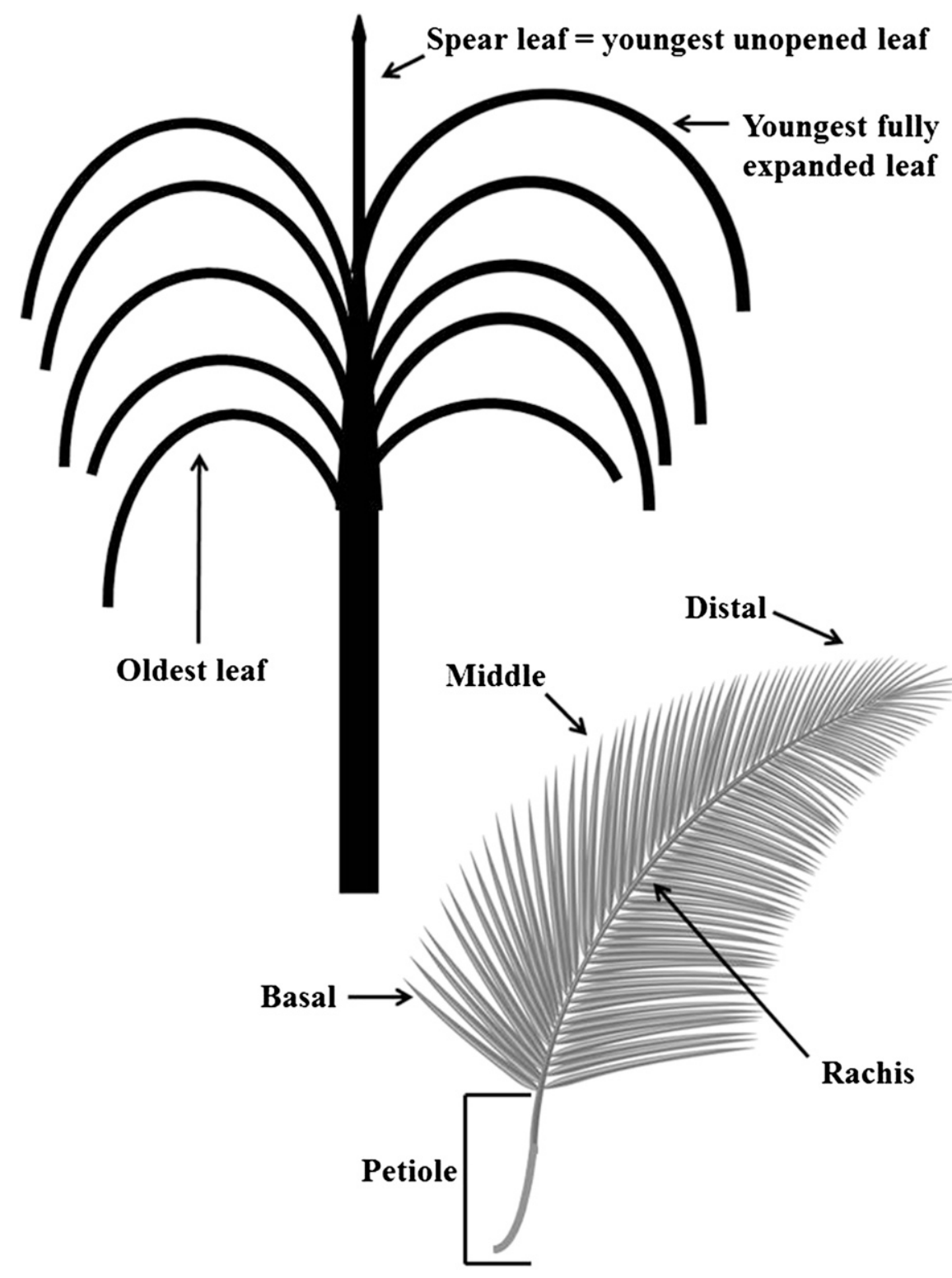

Fig. 1. Locations of palm tissues sampled for phosphite analysis. phosphite concentrations were determined to be very low and were not expected to change over time, these palms were not sampled after week 1 .

On 11 Feb. 2013, 40 weeks after injection of potassium phosphite, samples of the following plant tissues were harvested from the $90 \mathrm{~mL}$ potassium phosphite treated palms for phosphite analysis: spear leaf tip (SPR), rachis base from an old leaf (OBR), rachis base from the youngest fully expanded leaf (YBR), distal portion of the rachis of an old leaf (ODR), distal portion of the rachis of the youngest fully expanded leaf (YDR), basal leaflets from an old leaf (OBL), basal leaflets from the youngest fully expanded leaf (YBL), distal leaflets from the youngest fully expanded leaf (YDL), distal leaflets from an old leaf (ODL), basal half of the distal leaflets from an young leaf(YDLB), and distal half of the distal leaflets from an young leaf (YDLD) (Fig. 1)

Plant samples were dried at $60{ }^{\circ} \mathrm{C}$ for $48 \mathrm{~h}$ and ground in a Wiley Mill to pass through a 40-mesh screen. Homogeneous powder samples $(0.5 \mathrm{~g})$ were extracted with $10 \mathrm{~mL}$ DI, shaken by Labquake shaker (Labindustries Inc., Berkeley, CA) at 75 OPM for $10 \mathrm{~min}$ and centrifuged for $10 \mathrm{~min}$ at $2400 \mathrm{rpm}$. The liquid supernatant was then filtered through a $0.22-\mu \mathrm{m}$ nylon membrane filter using a vacuum pump. The filtrate was collected and refiltered through $\mathrm{C}_{18}$ SEP-PAK Cartridges (Waters Assoc., Milford, MA). This filtrate was then brought to a final sample volume of $5 \mathrm{~mL}$ with DI. Samples were kept frozen at $-11^{\circ} \mathrm{C}$ until they could be analyzed.

Samples were injected by hand using a 5-mL syringe into a Dionex-100 Ion Chromatograph (Model DX1-03; Dionex Corp., Sunnyvale, CA) with integrated Anion Self-regenerating Suppressor-Ultra, an AS-17 column and eluent gradient system (Kratos Analytical, Spring Valley, NY), and were eluted with $100 \mathrm{~mm}$ potassium hydroxide $(\mathrm{KOH})$ at a flow rate of

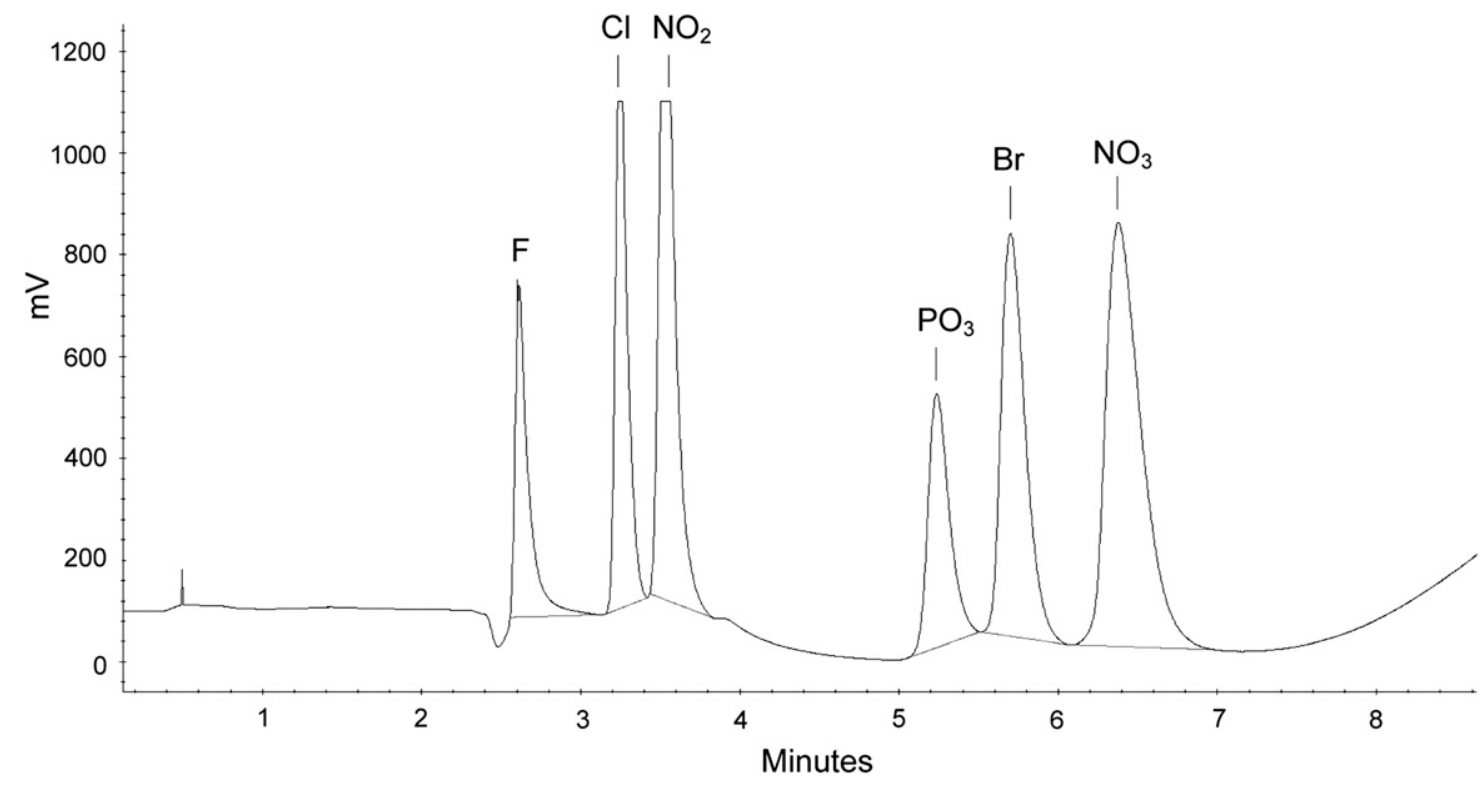

Fig. 2. Sample chromatogram showing elution times for phosphite and other anions. 
$0.56 \mathrm{~mL} \cdot \mathrm{min}^{-1}$. Eighteen percent $\mathrm{KOH}$ was initiated at $0 \mathrm{~min}$ and maintained until 0.45 min. A linear gradient of $18 \%$ to $100 \% \mathrm{KOH}$ was applied between 0.45 and $5.45 \mathrm{~min}$. The eluent of $100 \% \mathrm{KOH}$ was continued for $2 \mathrm{~min}$ to elute samples before decreasing to $18 \%$ $\mathrm{KOH}$ for postrun equilibrium. A conductivity detector detected anions and the data were processed using Peak Net Data Acquisition System (Dionex Corp., Sunnyvale, CA). A sample chromatogram showing the elution times for phosphite and other anions using this method is shown in Fig. 2. Treatment mean data for each tissue type were analyzed within and among sampling dates by regression analysis. Differences in means for each tissue type for the $90 \mathrm{~mL}$ treatment at week 40 were analyzed using Welch's analysis of variance, due to nonhomogeneity of variances. Mean separations were performed using the Waller-Duncan k-ratio (k-ratio = 100) method (SAS version 9.2, SAS Systems, Cary, NC).

\section{Results}

Phosphite concentrations in basal rachis tissue of the oldest leaves (OBR) reached a maximum of $713 \mu \mathrm{g} \cdot \mathrm{g}^{-1}$ at week 1 for the 90 $\mathrm{mL}$ rate and remained above $200 \mu \mathrm{g} \cdot \mathrm{g}^{-1}$ throughout the 60 weeks of the experiment (Fig. 3). The two lower application rates generally had statistically lower phosphite concentrations from the $90 \mathrm{~mL}$ rate for all sampling dates except week 20.

In the spear leaf tip, phosphite concentrations gradually increased until $\approx 10$ weeks when they reached a maximum of $769 \mu \mathrm{g} \cdot \mathrm{g}^{-1}$ for the $90 \mathrm{~mL}$ treatment, but less than 300 $\mu \mathrm{g} \cdot \mathrm{g}^{-1}$ for the 30 and $60 \mathrm{~mL}$ treatments (Fig. 3). The concentration of phosphite for the $90 \mathrm{~mL}$ treatment had decreased 5 weeks later by almost $50 \%$. Time effects were statistically significant $(P=0.03)$ for the 90 $\mathrm{mL}$ treatment, but nonsignificant for the 30 and $60 \mathrm{~mL}$ treatments. From 15 to 60 weeks, phosphite concentration declined only slightly for all three treatments. Treatments were significantly different $(P<0.0001)$ only at weeks 10 and 15.

Unlike the spear leaf, leaflets of both young (YML) and old (OML) leaves took up phosphite immediately after application, followed by a steep decline in the concentration 4 weeks later. Time effects were statistically significant $(P<0.0001)$ for all three phosphite treatments for both leaf ages. The primary differences between leaflets of young and old leaves were the significantly $(P<0.0001)$ greater concentrations of phosphite in young leaves and less persistence in old leaves (no phosphite detected after 40 weeks). For young leaves, phosphite concentrations peaked 1 week after application at $325 \mu \mathrm{g} \cdot \mathrm{g}^{-1}$ for the $30 \mathrm{~mL}$ treatment, 519 $\mu \mathrm{g} \cdot \mathrm{g}^{-1}$ for the $60 \mathrm{~mL}$ treatment, and 894 $\mu \mathrm{g} \cdot \mathrm{g}^{-1}$ for the $90 \mathrm{~mL}$ treatment (Fig. 3). Phosphite concentrations dropped rapidly thereafter and remained below $200 \mu \mathrm{g} \cdot \mathrm{g}^{-1}$ for all treatments through week 60 . Treatment differences were significantly different
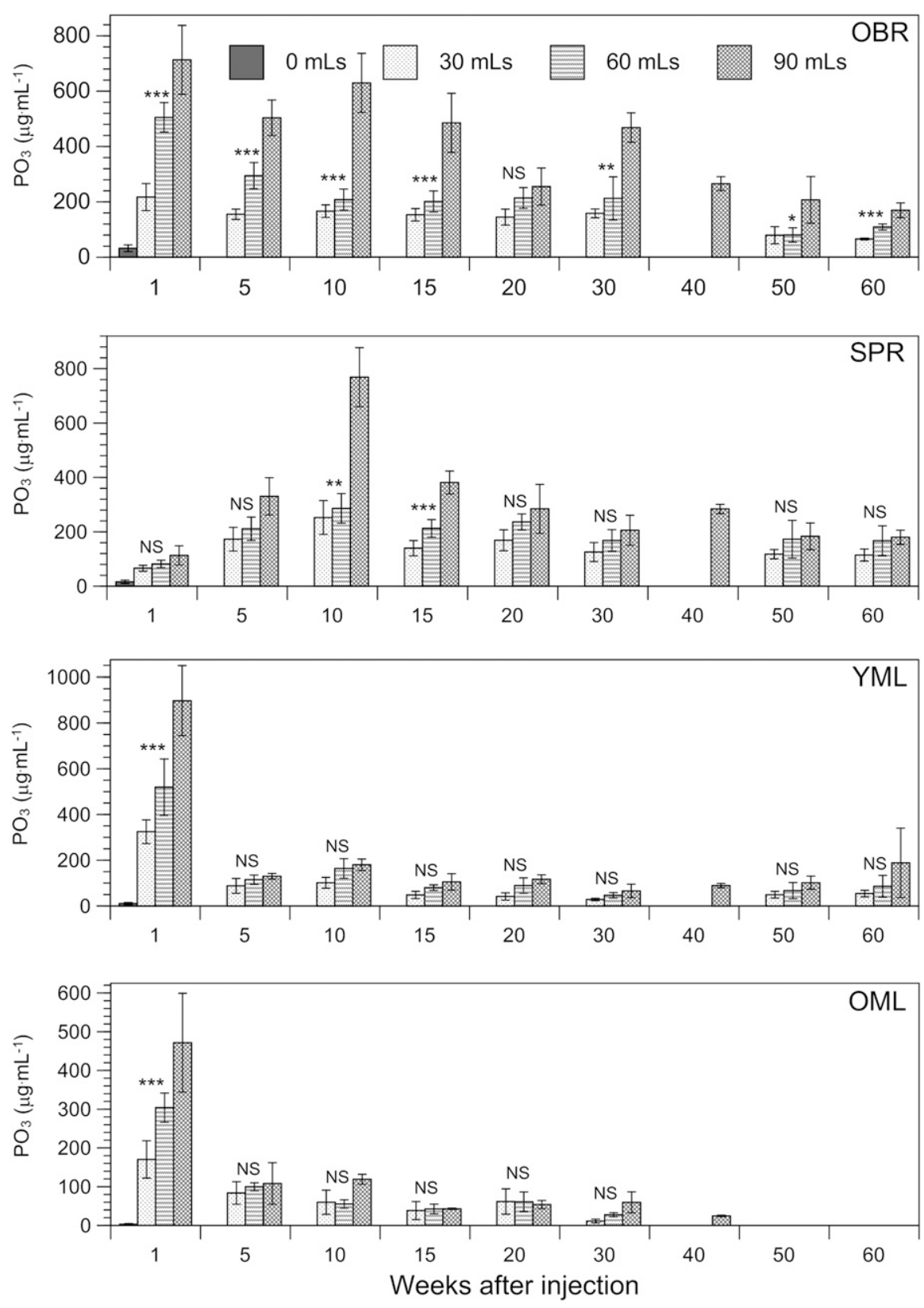

Fig. 3. Phosphite concentrations over a 60 -week period in various leaf tissues of coconut palms injected with $0,30,60$, or $90 \mathrm{~mL}$ of potassium phosphite. $\mathrm{OBR}=$ rachis base of oldest leaf; SPR = spear leaf tip; $\mathrm{YML}=$ middle leaflets of young leaf; and $\mathrm{OML}=$ middle leaflets of oldest leaf. Data are means of five replicate samples with standard error bars. ${ }^{* *}, * * *$, and Ns indicate statistical significance at $P=0.05$, $0.01,0.001$, and nonsignificant, respectively, for treatment means within each sampling date using linear regression analysis.

only at week 1 . For old leaves, phosphite concentrations peaked at $\approx 170$ for the $30 \mathrm{~mL}$ rate, 304 for the $60 \mathrm{~mL}$ rate, and $472 \mu \mathrm{g} \cdot \mathrm{g}^{-1}$ for the $90 \mathrm{~mL}$ rate (Fig. 3), and then gradually decreased to $\approx 25 \mu \mathrm{g} \cdot \mathrm{g}^{-1}$ by week 40 . Again, treatments were significantly different $(P<$ 0.0001 ) only at week 1 .

At 40 weeks after injection with $90 \mathrm{~mL}$ potassium phosphite, 11 different parts of the coconut palm were sampled and phosphite concentrations were determined. The spear leaf tips (SPR) contained an average of $284 \mu \mathrm{g} \cdot \mathrm{g}^{-1}$ phosphite (Fig. 4), and similar phosphite concentrations were detected in the rachis base of a young leaf (LBR) and rachis base of an old leaf (OBR). However, phosphite concentrations in SPR were greater than concentrations in all other leaf tissues sampled. Leaf rachis basal tissue of both young (YBR) and old (OBR) leaves had higher phosphite concentrations than more distal parts of the same leaves and all leaflet tissue. For the same plant position, tissue from young leaves generally had higher phosphite concentrations than older leaves. Phosphite concentrations in old leaves were similar for basal (OBL) and distal (ODL) leaflets, but for young leaves, basal leaflets (YBL) contained about four times as much phosphite as distal ones (YDL). Within young distal leaflets, the basal half of these leaflets (YDLB) contained 


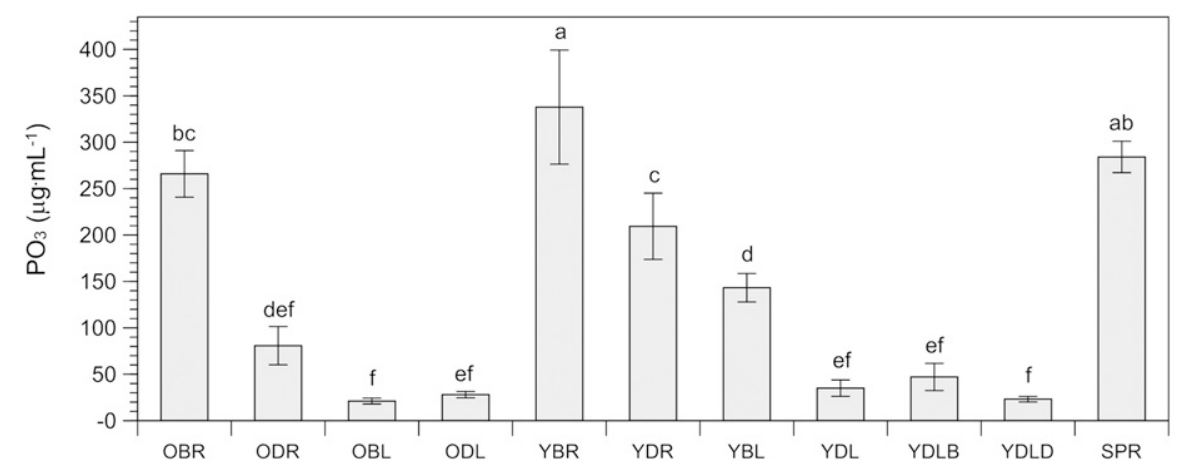

Fig. 4. Phosphite concentrations in various leaf tissues 40 weeks after trunk injection with $90 \mathrm{~mL}$ of potassium phosphite. $\mathrm{OBR}=$ old leaf, rachis base; ODR = old leaf, distal rachis; $\mathrm{OBL}=$ old leaf, basal leaflets; $\mathrm{ODL}=$ old leaf, distal leaflets; YBR = youngest fully expanded leaf, rachis base; YDR = youngest fully expanded leaf, distal rachis; YBL = youngest fully expanded leaf, basal leaflets; YDBL = youngest fully expanded leaf, basal portion of distal leaflets; YDLD = youngest fully expanded leaf, distal portion of distal leaflets; and SPR = spear leaf. Data are means of five replicate samples with standard error bars. Means with similar letters on bars are not significantly different at $P=0.05$.

similar amounts of phosphite as the distal half (YDLD).

\section{Discussion}

Trunk injection was found to be an effective method of moving phosphite into palm leaf tissue, as it has been for woody dicot trees (Bezuidenhout et al., 1987; Guest et al., 1994; VanWoerkom et al., 2014). Phosphite appears to be highly mobile within coconut palms, having a distribution at 40 weeks after injection similar to that of potassium and phosphate (Broschat, 1997). This ion appeared at high concentrations in young and old leaflets within 1 week, but by week 5 , concentrations in these tissues dropped sharply, presumably due to translocation into newly developing leaves. Phosphite concentrations reported for various parts of avocado trees were much lower than those obtained from coconut palms in this study, but this may be due to differences in application rates (Bezuidenhout et al., 1987).

It is important that fungicides accumulate and persist in plant tissue that is the site of infection for a particular pathogen. This study shows that phosphite accumulates and persists in spear leaves and the basal rachis tissue of new and old leaves but not leaflets of coconut palms, suggesting that it may be useful for preventing diseases infecting these tissues, but not those infecting leaflet tissue. This may explain previous research results where trunk-injected phosphite reduced bud rot and nut drop in coconut palm caused by Phytophthora spp., a pathogen that initially infects spear leaves (DeFranqueville and Renard, 1989; Pohe et al., 2003; Thévenin et al., 1995). Our study showed that phosphite persisted in basal rachis tissue and was found in new spear leaves at concentrations between 100 and $200 \mu \mathrm{g} \cdot \mathrm{g}^{-1}$ for at least 60 weeks after the phosphite injection. These concentrations are within the range found to directly inhibit mycelial growth in vitro for some species of Phytophthora (Guest and Grant, 1991). Phosphite movement tends to be regulated by source-sink relationships petioles or rachises of old leaves may be prevented or damage reduced (Elliott et al., 2004, 2010). Phosphite has been shown to reduce mycelial growth in these and other formae speciales of $F$. oxysporum in vitro (Davis et al., 1994; J. Yu, unpublished data) and has reduced the severity of diseases caused by other Fusarium sp. in potato and winter wheat (Hofgaard et al., 2010; Lobato et al., 2008). Additional research is needed to determine how effective phosphite will be in managing specific diseases of palms in the field or landscape.

\section{Literature Cited}

Bezuidenhout, J.J., J.M. Darvas, and J.M. Kotze. 1987. The dynamics and distribution of phosphite in avocado trees treated with phosetyl-Al. South African Avocado Growers'. Assoc. Yearbook 10:101-103.

Broschat, T.K. 1997. Nutrient distribution, dynamics, and sampling in coconut and Canary Island date palms. J. Amer. Soc. Hort. Sci. 122:884-890.

(Guest and Grant, 1991). In this case, the source is leaflet tissue of existing leaves and the sink is the newly emerging spear leaf. It is not clear why phosphite accumulated in basal rachis tissue as this tissue is composed primarily of vascular bundles with few parenchyma cells, which might store phosphite. Another trunk-injected fungicide, thiabendazole, has also been shown to accumulate and persist in petiole and rachis tissue, but not leaflet tissue of coconut palms (Elliott and Broschat, 2012). In avocado tree, Bezuidenhout et al. (1987) found that phosphite accumulated predominantly in old branches, tissue that is functionally analogous, though anatomically very different, to palm basal rachis tissue.

Although Pohe et al. (2003) injected fosetyl-Al three times per year at rates lower than those used in our study (3.2-6.4 g a.i.), such frequent applications may not be necessary. DeFranqueville and Renard (1989) noted a significant reduction in nutfall of coconut palm caused by Phytophthora heveae when fosetyl-Al was injected annually at rates of 1.6-4.8 g a.i. Similarly, Thévenin et al. (1995) injected coconut palms twice with foseytl-Al or buffered phosphorous acid at rates of 3-20 g a.i. at 20-month intervals and had excellent suppression of Phythophthora bud rot at 3 years after the first injection. Phosphite concentrations in old branches of avocado remained relatively high at 17 months following injection (Bezuidenhout et al., 1987).

In summary, this study shows that trunk injection of potassium phosphite into mature coconut palms results in an accumulation of phosphite in basal rachis tissue as well as new spear leaves for at least 60 weeks. This material thus has potential for controlling pathogens that initially infect the spear leaf, as has been shown for Phytophthora bud rot, and petiole or rachis tissue, but not those pathogens that infect leaflet tissue. The persistence of phosphite in petiole and rachis tissue suggests that pathogens, such as the two formae speciales of Fusarium oxysporum, that usually infect ornamental palms via
Darakis, G., P. Blizoua-Bi, T. Barchietto, J.L. Renard, P. Saindrenan, and G. Bompeix. 1985. Distribution du phosetyl-Al dans les tissus de cocotier après traitement: Hypothesis sur son mode d'action sur le Phytophthora heveae. Fungicides for Crop Protection Monograph No. 31 .

Davis, A.J., M. Say, A.J. Snow, and B.R. Grant. sp. cubense to phosphonate. Plant Pathol. 43:200-205.

DeFranqueville, H. and J.L. Renard. 1989. Effectiveness of Fosetyl-Al in controlling Phytophthora of coconut. Application methods. Oleagineux 44:351-358.

Elliott, M.L. and T.K. Broschat. 2012. Detection of thiabendazole fungicide in coconut palms using a bioassay. Palms 56:21-27.

Elliott, M.L., T.K. Broschat, J.Y. Uchida, and G.W. Simone. 2004. Compendium of diseases and disorders of ornamental palms. Amer. Phytopath. Soc. Press, St. Paul, MN.

Elliott, M.L., E.A. Des Jardin, K. O’Donnell, D.M. Geiser, N.A. Harrison, and T.K. Broschat. 2010. Fusarium oxysporum f. sp. palmarum, a novel forma specialis causing a lethal disease of Syagrus romanzoffiana and Washingtonia robusta in Florida. Plant Dis. 94:31-38.

Guest, D.I., R.D. Anderson, H.J. Foard, D. Phillips, S. Worboys, and R.M. Middleton. 1994. Longterm control of Phytophthora diseases of cocoa using trunk-injected phosphonate. Plant Pathol. 43:479-492.

Guest, D. and B. Grant. 1991. The complex action of phosphonates as antifungal agents. Biol. Rev. Camb. Philos. Soc. 66:159-187.

Guest, D., K.G. Pegg, and A.W. Whiley. 1995. Control of Phytophthora diseases of tree crops using trunk-injected phosphonates. Hort. Rev. 17:299-330.

Hofgaard, I.S., A. Ergon, B. Henriksen, and A.M. Tronsmo. 2010. The effect of potential resistance inducers on development of Microdochium majus and Fusarium culmorum in winter wheat. Eur. J. Plant Pathol. 128:269-281.

Lobato, M.C., F.P. Olivieri, G.R. Daleo, and A.B. Andreu. 2010. Antimicrobial activity of phosphites against different potato pathogens. Plant Diseases and Protection 117(3):102-109.

Lobato, M.C., F.P. Olivieri, E.A. Gonzalez Altamiranda, E.A. Wolski, G.R. Daleo, D.O. Caldiz, and A.B. Andreu. 2008. Phosphite compounds reduce disease severity in potato seed 1994. Sensitivity of Fusarium oxysporum f 
tubers and foliage. Eur. J. Plant Pathol. 122:349-358.

McDonald, A.E., B.R. Grant, and W.C. Plaxton. 2001. Phosphite (phosphorous acid): Its relevance in the environment and agriculture and influence on plant starvation response. J. Plant Nutr. 24:1509-1519.

Ouimette, D.G. and M.D. Coffee. 1990. Symplastic entry and phloem translocation of phosphonate. Pestic. Biochem. Physiol. 38:18-25.

Pohe, J., B.K. Dongo, and N. N'Goran. 2003. Effectiveness of aluminum-fosetyl in the control of early nutfall of coconut tree due to
Phytophthora katsurae (Pythiaceae). Agronomie Africaine 15(3):123-133.

Ratjen, A.M. and J. Gerendás. 2009. A critical assessment of the suitability of phosphite as a source of phosphorus. J. Plant Nutr. Soil Sci. 172:821-828.

Smillie, R., B.R. Grant, and D. Guest. 1989. The mode of action of phosphite: Evidence for both direct and indirect modes of action on three Phytophthora spp. in plants. Phytopathology 79:921-926.

Thao, H.T.B. and T. Yamakawa. 2009. Phosphite (phosphorous acid): Fungicide, fertilizer, or biostimulator? Soil Sci. Plant Nutr. 55:228234.

Thévenin, J.M., H.F.J. Motulo, S. Kharie, and J.L. Renard. 1995. Lutte chimique contre la pourriture du cœur à Phytophthora du cocotier en Indonésie. Phytopathologie. Plantations, Recherche. Développement 2:41-50.

VanWoerkom, A.H., S.G. Aćimović, G.W. Sundin, B.M. Cregg, D. Mota-Sanchez, C. Vandervoort, and J.C. Wise. 2014. Trunk injection: An alternative technique for pesticide delivery in apples. Crop Prot. 65:173-185. 